\title{
Cytotoxic Effect of Jati Belanda Leaves towards Cancer Cell Lines
}

\author{
Muhammad Da'i \\ Faculty of Pharmacy, Universitas Muhammadiyah Surakarta, Indonesia
}

\begin{abstract}
The initial research of Jati Belanda leaves extract (JBE) showed the inhibition of breast cancer cell growth (T47D). The phytochemistry screening showed that JBE contain flavonoid, alkaloid, polifenol, and volatile oil. The development of anticancer drugs need the molecular mechanism investigation in order to produce cancer-targeted drugs. The objective of this research is to determine the molecular mechanism of JBE cytotoxicity effect towards cancer cell lines. This research began with cytotoxicity asssay in vitro of JBE towards some cancer cell lines by MTT method. JBE was given in some variety of concentration. The result of this study showed that JBE do not contain tirosid, and contain flavonoid in the concentration of $0.976 \%$. The result of cytotoxicity assay towards MCF-7, HeLa, T47D and Vero showed IC 50 value $36.50 ; 58.02 ; 53.36 ; 1806.22$ dan $2451.65 \mu \mathrm{g} / \mathrm{mL}$ respectively. It is concluded that JBE have a strong potency to inhibit the growth of WiDr cancer cell line.
\end{abstract}

Keywords : jati belanda, T47D cells, cytotoxicity

\section{INTRODUCTION}

Cancer is one of the disease causing the high prevalence of death in worldwide. Cancer is the uncontrol growth and development of the cells happened in the body. The insidence of some type of cancer disesase are increasing in some developing countries (Garcia, et al., 2007). Breast cancer and sevical cancer are the major types of cancer happens in Indonesian women (Tjindarbumi and Mangunkusumo, 2002). The development of cancer mostly being diagnosted in the late phase of cancer growth (the metastatic stage) and involving the complex molecular mechanism.

Cancer usually happens because of the basic change in the cell physiology so that it becomes malignant. Generally, the main characteristic of cancer cells are: a) sufficient in growth signal to control the cell cycle, b) insensitive to anti-growth factor thus the cycle cell becomes unstoppable, c) lack of apoptotic ability, d) cell invassion to the other tissue and blood stream, so the cell become metastatic to other tissue, e) unlimited replication potency (immortal), f) the ability to make new blood vessel for the cancer cells (angiogeneis) (Hanahan \& Weinberg, 2000).

Some strategies in cancer therapy have been done intensively, such as surgery, chemotherapy, and radiotherapy. From those therapy strategies, chemoteraphy is the most preferable choice of therapy to be done in the late phase of cancer (metastatic phase). Chemotherapy is a therapy by using chemical substances worked in cancer cell. Some of chemotherapy agent usually used in the breast cancer treatment are Adriamycin (Doxorubicin), Aredia (Pamidronate disodium), Cytoxan (Cyclophosphamide), Ellence (Epirubicin), Fareston (Toremifene), Tamoxifen (Nolvadex), Taxol (Paclitaxel), and Taxotere (Docetaxel). The failure of the chemotherapy treatment usually caused by the low level of selectivity and sensitivity of the cancer cells towards chemotherapy agent. The effort to develop new drugs that safer and more selective for the treatment and prevention of cancer by knowing the molecular effect towards cancer cell is needed to be done.

*Corresponding author e-mail: abulathfi@yahoo.com 
Some of anticancer agent from plants have been used in chemotherapy of cancer effectively. Alkaloid vincristine, vinblastine, and taxol are the example of anticancer drugs that have been used for a long time and their molecular mechanism have been known (Cragg and Newman, 2005). The scientific theory for the molecular effect of plants substances in the development of anticancer agent is needed to be known.

Jati belanda plants, especially its leaves, have been used in the traditional medical therapy. The research about its activity have been done recently. Traditionally, this plant is used as body weight lowering tea and the treatment for some disease such as malaria, diare, gonarrhae, liver and kidney disturbance, hemorrhoids, and can stimulate uterus contraction (Anonymous, 2009). The antibacterial and antiviral activity of Jati Belanda has been reported to inhibit the pancreatic lipase activity (Iswantini, et al., 2011) and its water extract has been reported to lower the lipid concentration in rats (Sukandar, et al., 2009).

This research was done to determine the selectivity of cytotoxic activity by ethanolic extract of jati belanda leaves towards several cancer cell lines in vitro. This research was done to study about the antiproliferative and anticancer mechanism of Jati Belanda leaves ethanolic extract with the observation of protein expression related to the cancer cell proliferation by doubling time assay and flowcytometry. Beside, this research's objective is to study about the molecular mechanism in the induction of cancer call apoptosis process by double staining method. The molecular mechanism was observed by immunocytochemistry method and western blott.

The in vitro cytotoxicity then continued by the cellular and molecullar level observation to know the molecullar target that specific to cancer cell, such as transduction signalling, cell cycle regulation, apoptosis, and angiogenesis process. The alteration of morfological characteristic and DNA fragmentation showed the antiproliferative activity that caused by the apoptosis induction has been observed in several medicinal plants (Ueda, et al., 2002). The cytotoxic activity mechanism by Jati Belanda ethanolic extract in this research was begun with the cellular level observation in the cell cycle and apoptosis regulation.

The investigation of molecular mechanism could be done by observing the expression level of certain proteins (Kuo, et al., 2005; Malikova, et al., 2006). The cell cycle regulation based on cyclins and cyclindependent kinases (CDKs) is the regulation which iniciate the cycle process from G1 phase to $\mathrm{S}$ phase continued to mitotic phase. Cancer usually happens because of the uncontrolable cyclin-dependent kinase activity by cell cycle inhibitor such as p21 (Malikova, et al., 2006). The observation of cell cycle protein regulation expresion is one of the specific molecular mechanism regulation. The apoptotic induction in tumor cell reputed as a useful method in the therapy and prevention of cancer. Some natural products have been proven to have the ability in apopototic induction in human cancer cell (Taraphdar, et al., 2001). This research was done in the molecular mechanism investigation by observing gene/protein expression based on immunocytochemistry and western blott method in some gene/ protein related to the cell cycle regulation in $\mathrm{G} 2 \mathrm{M}$ phase, such as $\mathrm{p} 53$, $\mathrm{p} 21$, and cdc-2, and several proteins related to the apoptotic process such as p53, BAX, PUMA, Caspase-3, Caspase-7, Caspase-8, Caspase 9, and PARP.

\section{MATERIALS AND METHODS}

\section{Extract Preparation}

About $5 \mathrm{~kg}$ simplisia powder of jati belanda leaves was macerated by using etanol $15 \mathrm{~L}$. The mixture then settled for 2 days in light-protected place, stirred occasionally. Maserate then filterred by using Buchner funnel and settled for one day. The precipitate was separated from filtrate and fractionated with diethyleter to remove tannin substances. Then it was evaporated by using vaccum rotary 
evaporator to get the ethanolic extract of jati belanda leaves.

\section{Determination of Tilirosid Content}

One gram of extract were dissolved in 5 $\mathrm{mL}$ of methanol and sonicated for 5 minutes. Then it was fractionated by separation funnel with Hexane for 3 times. The residue of methanol fraction were added by ethyl acetate until $10 \mathrm{~mL}$ of volume. Extract solution and Tilarosied solution sample were spotted for 15 $\mu \mathrm{L}$ volume in Silica Gel F254, and then elluted by Toluene-ethyl acetate-formic acid (4:6:1 $\mathrm{mL}$ ) in $8 \mathrm{~cm}$ of ellution. The spot were detected by Sitroborat and heated in $110^{\circ} \mathrm{C}$ for 10 minutes.

\section{The determination of Total Flavonoid Content}

About $200 \mathrm{mg}$ extract were weighed accurately. The sample were hidrolysed by the addition of $1 \mathrm{~mL}$ hexanemethylentetramine $0.5 \%, 20 \mathrm{~mL}$ acetone, and $2 \mathrm{ml} \mathrm{HCl} 25 \%$ in the water, then heated until it boiled (by using reflux method) for 30 minutes. The hydrolized mixture were filtered, and put into the $25.0 \mathrm{~mL}$ measure funnel. The residue were hydrolized again by the addition of $20 \mathrm{~mL}$ acetone for two times, and the filtrate were accumulated in the measure funnel. After the solution's temperature was decreased, the volume were added in to $25.0 \mathrm{~mL}$ with acetone, and shook homogenously. About $10 \mathrm{~mL}$ of filtrate were added by $20 \mathrm{~mL}$ of aquadest and put in to the separation funnel, and then the extraction continued by adding $10 \mathrm{~mL}$ ethyl acetate for two times and $5 \mathrm{~mL}$ ethyl acetate until $25.0 \mathrm{~mL}$ of ethyl acetate fraction were obtained. The ethyl acetate fraction then added in to $25.0 \mathrm{~mL}$ of volume with ethyl acetate. This procedure were replicated for three times.

\section{The Cytotoxicity Assay}

The cytotoxicity assay of the cell culture with the treatment of some concentration of tested substances were done by using MTT assay method in 96 well plate. The suspension of T47D cells were cultured in the well-plate as many as $1.5 \times 10^{4}$ each plate for 24 hours in $100 \mu \mathrm{L}$ of culture media.

The media were added by the ethanolic extract of Jati Belanda leaves in the concentration of $12.5 \mu \mathrm{g} / \mathrm{mL} ; 25 \mu \mathrm{g} / \mathrm{mL} ; 50$ $\mu \mathrm{g} / \mathrm{mL} ; 100 \mu \mathrm{g} / \mathrm{mL} ; 250 \mu \mathrm{g} / \mathrm{mL} ;$ and 500 $\mu \mathrm{g} / \mathrm{mL}$, and were incubated for 24 hours. After the incubation were done, the culture media were removed and the cells were washed by PBS for 1 times, and added by $100 \mu \mathrm{L}$ new culture media and added by $150.0 \mu \mathrm{L}$ MTT $5 \mathrm{mg} / 1.5 \mathrm{~mL}$ for 4 hours of incubation. The reaction with MTT reagent were stopped by SDS solution and incubated in the room temperature for 24 hours. The living cells would react with MTT to become purple in colour, and the colour absorbace were measured by using ELISA reader in the $550 \mathrm{~nm}$ wavelength. The absorbance or the number of the living/death cells were plottes in to the precentage of the death cells versus concentration of the tested compound, and were quantify for $\mathrm{IC}_{50}$ value.

\section{Cell Growth Analysis}

The suspension of T47D cells were cultured in the well-plate as many as $1.5 \times 10^{4}$ cells each plate for 24 hours in $100 \mu \mathrm{L}$ of culture media. The media were added by the ethanolic extract of jati belanda leave in the concentration of $12.5 \mu \mathrm{g} / \mathrm{mL} ; 25 \mu \mathrm{g} / \mathrm{mL} ; 50$ $\mu \mathrm{g} / \mathrm{mL}$. Cell were observed in $6,12,24,56$, and 72 hours of incubation by using MTT method. The media of the cell that being observed were removed and washed by using PBS. Then, the cell were added with culture media as many as $100 \mu \mathrm{L}$ and added with MTT reagent $150.0 \mu \mathrm{L}$ $5 \mathrm{mg} / 1.5 \mathrm{~mL}$. After the incubation formazan crystal were dissolved by SDS solution, and the absorbance were obtained by using ELISA reader in $550 \mathrm{~nm}$ of wavelenght. The difference of doubling time could be obtained by the slope of the curve or by the extrapolation calculation.

\section{Observation of Cell Morohology}

The cell morphology were observed by using acridine orange staining under the light microscope. 


\section{Apoptosis Assay by double staining method}

Approximately 100.000 cells were cultured on the cover slips. After 24 hours of incubation in $\mathrm{CO}_{2} 5 \%, 37^{\circ} \mathrm{C}$, the cells were treated by the ethanolic extract of Jati Belanda leaves in several concentration. The cells were incubated for 24 hours. After the incubation, the culture media were removed and the cell were added by etidium bromide and acridine orange solution. The morphological alteration were observed under the fluorosence microscope, the living cell will be stained in green colour, meanwhile the death cell stained in red colour.

\section{Data Analysis}

The research result were showed as absorbance value of formazan complex in cytotoxicity assay is converted to be the cell death precentage by this formula:

$$
\% \text { death cell }=\frac{(\text { Abs of control cell }- \text { Abs of treated cell })}{\text { Absof control cell }} \times 100 \%
$$

The death cell was analyzed by linier regretion as converted to the probit data value. The plot chart of axis was log of concentration, meanwhile the orbital was the probit value. The $\mathrm{IC}_{50}$ value was obtained by the determination of axis value in the probit level 5 which means the cells that died were $50 \%$.

The analysis for the doubling time of the cell were determined by the plot of the chart axis value (time) versus ordinat value (logarithm of the cell number). The doubling time was counted $b$ the linier regretion. The determinatin of cell precentage which is express the certain gene/protein was counted by this formula:

$$
\% \text { Expression }=\frac{\text { cell expressing protein }}{100 \text { number of cell }} \times 100 \%
$$

\section{RESULT AND DISCUSSION}

The flavonoid rutin concentration based on the linear regression equation (Table 1) is $0.976 \%$. The ethanolic extract of Jati Belanda leaves showed variation in cytotoxic effect. The highest $\mathrm{IC}_{50}$ value was obtained by Vero cell lines and the highetst activity of the extract were towards WiDr, MCF-7, and HeLa cell lines (Table 2).

Based on the apoptosis observation by using acridine orange-etidium bromide showed the potency of extract to induce apoptosis in MCF-7 and HeLa cell (Fig. 1 and 2).

Table I. Linear regression for rutin concentration in Jati Belanda leaves extract

\begin{tabular}{cccc}
\hline \multirow{2}{*}{ Concentration $(\mu \mathrm{g} / \mathrm{mL}) \times 10^{-3}$} & \multicolumn{2}{c}{ Abs } & Mean of Abs \\
\cline { 2 - 3 } 1.58 & R.I & R.2 & \\
3.96 & 0.117 & 0.123 & 0.12 \\
7.92 & 0.483 & 0.476 & 0.479 \\
11.88 & 0.891 & 0.897 & 0.894 \\
15.84 & 1.072 & 1.193 & 1.133 \\
\hline
\end{tabular}

Linear regression: $Y=86.87 X+0.089$ 
Table 2. Cytotoxicity Effect of Jati Belanda Leaves Ethanolic Extract in Some Cell Lines

\begin{tabular}{|c|c|c|c|c|c|c|c|}
\hline \multirow{2}{*}{ No. } & \multirow{2}{*}{ Result } & \multicolumn{6}{|c|}{ Cancer cell lines } \\
\hline & & WiDR & MCF7 & HeLa & T47D & Raji & Vero \\
\hline I & $\begin{array}{l}\text { Linear } \\
\text { regression } \\
\text { equation }\end{array}$ & $\begin{array}{l}y=-30.65 x \\
+97.88\end{array}$ & $\begin{array}{l}y=-27.20 x \\
+97.97\end{array}$ & $\begin{array}{l}y=-26.298 x \\
+95.42\end{array}$ & $\begin{array}{l}y=-32.53 x \\
+155.93\end{array}$ & - & $\begin{array}{l}y=-41.66 x+ \\
191.22\end{array}$ \\
\hline 2 & $\mathrm{R}$ & -0.8993 & -0.8898 & -0.9318 & -0.8817 & - & -0.7540 \\
\hline 3 & $\mathrm{IC}_{50}(\mu \mathrm{g} / \mathrm{mL})$ & 36.50 & 58.02 & 53.36 & 1806.22 & - & 2451.65 \\
\hline
\end{tabular}

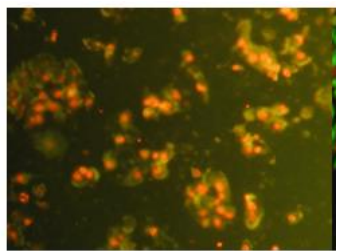

(A)

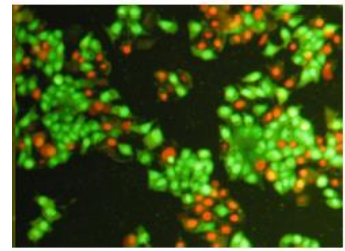

(B)

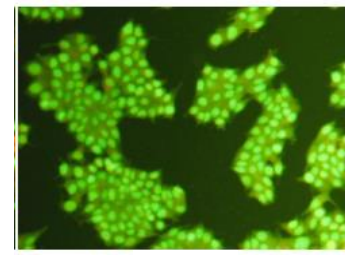

(C)

Figure I. The morphology of MCF-7 cell with acridine orange and etidium bromide staining in the treatment of (A) Jati Belanda ethanolic extract $58.02 \mu \mathrm{g} / \mathrm{mL}$, (B) Jati Belanda ethanolic extract $29.00 \mu \mathrm{g} / \mathrm{mL}$ and (C) control cell. The result showed that the treatment of Jati Belanda ethanolic extract induce apoptosis of the cell.

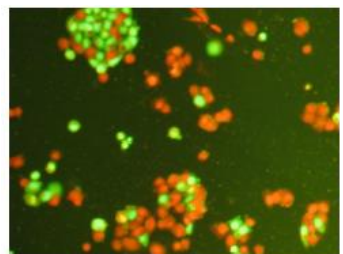

(A)

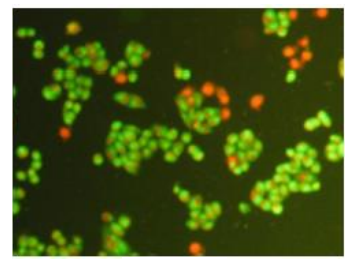

(B)

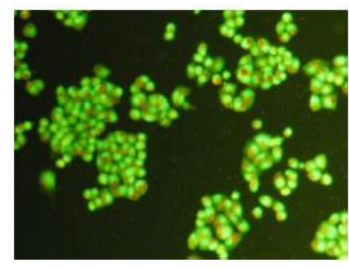

(C)

Figure 2. The morphology of HeLa cell with acridine orange and etidium bromide staining in the treatment of (A) Jati Belanda ethanolic extract $53.36 \mu \mathrm{g} / \mathrm{mL}$, (B) Jati Belanda ethanolic extract $26.50 \mu \mathrm{g} / \mathrm{mL}$ and $(C)$ control cell. The result showed that the treatment of Jati Belanda ethanolic extract induce apoptosis of the cell.

This study showed the potency of jati belanda ethanolic extract as cytotoxicity agen that is spesific towards colon cancer cell (WiDr), breast cancer cell (MCF-7), and servix cancer cell (HeLa). The mechanism of apoptosis in the treatment of the extract to the cell showed that extract could influence the cell death regulation through molecular mechanism.

The initial research done by the team showed that Jati Belanda ethanolic extract contain alkaloid, flavonoid, volatile oil, and polifenol substances (Melannisa, et al., 2011). Sukandar, et al. (2009) reported that alkaloid, flavonoid, tanin, and terpenoid are also contained in the pacar air simplisia and extract. The result of this study was in accordance to the research by Nascimento (1990) in KB cell. The procyanidin $B-2$ substances isolated from this plant showed the cytotoxic activity in Raji and melanoma cells, but inactive towards lung cancer cell A-549 (Kashiwada, et al., 1992; Ito, et al., 2002). 


\section{CONCLUSION}

Jati belanda ethanolic extract could inhibit the cancer cell proliferation specifically in colon cancer cell (WiDr), breast cancer cell (MCF-7), and servical cancer (HeLa) with $\mathrm{IC}_{50}$ value $36.50, \quad 58.02$ and $53.36 \mu \mathrm{g} / \mathrm{mL}$ respectively. Jati Belanda ethanolic extract also could induce apoptosis in the breast cancer cell (MCF-7) and cervical cancer cell (HeLa).

\section{ACKNOWLEDGEMENT}

We would like to say thank you to Higher Education Departement through Fundamental Grants.

\section{REFERENCES}

Anonymous, 2009, Guazuma ulmifolia Lamk, Laporan Penelitian Laboratorium Penetapan Mutu dan Keamanan Ekstrak, Faculty of Pharmacy, Universitas Muhammdiyah Surakarta, Surakarta.

Cragg, G. M. and Newman, D.J., 2005, Plants as a Source of Anti-Cancer Agents, J. Ethnopharmacol, I00(I-2), 72-79.

Felipe, A.M.M., Rincão, V.P., Benati, F.J., Linhares, R.E.C., Galina, K.J., de Toledo, C.E.M., et al., 2006, Antiviral Effect of Guazuma ulmifolia and Stryphnodendron adstringens on poliovirus and bovine herpesvirus, Biol. Pharm. Bulletin, 29(6), 1092-1095.

Garcia M., Jemal A., Ward E.M., Center M.M., Hao Y., Siegel R.L. and Thun M.J., 2007, Global Cancer Facts \& Figures 2007, Atlanta. GA: American Cancer Society.

Gibbsb, J.B., 2000, Mechanism-Based Target Identification and Drug Discovery in Cancer Research, Science, 287(5460), 1969-1973.

Hanahan, D. and Wienberg, R.A., 2000, The Hallmarks of Cancer, Cell, I00(I), 5770.

Iswantini, D., Silitonga, R. F., Martatilofa, E. and Darusman, L. K., 2011, Zingiber cassumunar, Guazuma ulmifolia, and Murraya paniculata Extracts as Antiobesity: In Vitro Inhibitory Effect on Pancreatic, HAYATI J. Biosci., I8(I), 6-10.

Ito, H., Kobayashi, E., Li, Sh., Hatano, T., Sugita, D., Kubo, N., et al., 2002, Antitumor Activity Of Compounds Isolated From Leaves Of Eriobotrya Japonica, J. Agric. Food Chem., 50(8), 2400-2403.

Kashiwada, Y., Nonaka, G., Nishioka, I., Chang, JJ. and Lee, K.H., 1992, Antitumor Agents, 129, Tannins And Related Compounds As Selective Cytotoxic Agents, J. Nat. Prod., 55(8), I033-1043.

Kuo, P.L., Hsu, Y.L., Chang, C.H. and Lin, C.C., 2005, The Mechanism of EllipticineInduced Apoptosis and Cell Cycle Arrest in Human Breast MCF-7 Cancer Cells, Cancer Lett., 223(2), 293301.

Malikova, J., Zdarilova, A. and Hlobilkova, A., 2006, Effects of Sanguinarine and Chelerythrine on the Cell Cycle and Apoptosis, Biomed. Pap. Med. Fac. Univ. Palacky Olomouc Czech. Repub., I50(I), 5-12.

Melannisa, R., Kusumowati, I.T.D, Da'i, M. and Yuliani, R., 20II, Efek Sitotoksik Daun Maitan, Daun Senggani dan Daun Jati Belanda Terhadap Sel Kanker Payudara T47D disampaikan pada Kongres IImiah XIX dan Rapat Kerja Nasional IAI 20II, 28-30 Oktoner 20II, Manado.

Nascimento, S.C., Chiappeta, A.A. and Lima, R.M.O.C., 1990, Antimicrobial And Cytotoxic Activities In Plants From Pernambuco, Brazil, Fitoterapia, 6I(4), 353-355.

Sukandar, E.Y., Farmakologi, K.K., Klinik, F., and Farmasi, S., 2009, Pengaruh Pemberian Ekstrak Air Daun Jati Belanda ( Guazuma Ulmifolia Lamk .) terhadap Kadar Lipid Darah pada Tikus Jantan, JKM, 8(2), I02-I I 2.

Taraphdar, A. K., Roy, M. and Bhattacharya, R.K., 200I, Natural Products as Inducers of Apoptosis : Implication for Cancer Therapy and Prevention, Curr. Sci., 80(I I), I 387-I 396.

Tjindarbumi, D. and Mangunkusumo, R., 2002, Cancer In Indonesia, Present and Future, Jpn. J. Clin. Oncol., 32(I), SI7S2I.

Tumbel, M., 2009, Uji Daya Hambat Ekstrak Metanol Daun Jati Belanda (Guazuma ulmifolia, Lamk) terhadap 
Da'i, et al., 2015

Indones. J. Cancer Chemoprevent., 6(2), 35-41

Pertumbuhan Eschericia coli, Chemica, I 0(2), 85-9I.

Ueda, J.Y., Tezuka, Y., Banskota, A.H., Tran, Q.

L., Tran, Q.K., et al., 2002,

\section{[iscc. II] IClC}

Antiproliferative Activity of Vietnamese Medicinal Plants, Biol. Pharm. Bull., 25(6), 753-760. 